\title{
RENOVATION OF MULTI-APARTMENT RESIDENTIAL BUILDINGS IN LATVIA
}

Intra LŪCE, College of Law, Kronvalda Bulv. 1A, Riga, LV-1010, Latvia, intra@jk.lv (corresponding author) Iveta AMOLIN̦A, Riga Technical University, 1 Kalku Street, Riga LV-1658, Latvia, iveta.amolina@rtu.lv Mārcis NEIBERGS, College of Law, Kronvalda Bulv. 1A, Riga, LV-1010, Latvia, mneibergs@gmail.com

\begin{abstract}
The origin of current climate change (unlike other past climate changes) is the increase in the so-called greenhouse effect. Several atmospheric gases are able to absorb infrared radiation intensively. Such gases are carbon dioxide (CO2), methane (CH4), water vapour, as well as nitrous oxide (N2O) and other gases. They are permeable to incoming radiation, but block the infrared (heat) radiation reflected from the earth's surface. These gases are called greenhouse gases. One of the solutions to reduce the greenhouse effect is to implement energy efficiency measures in multi-apartment residential buildings.

The total multi-apartment housing stock in Latvia continues to age. Most residential buildings in Latvia were built during the Soviet period (1946-1990), the second largest category - even before the Second World War. Only a very small proportion of buildings have been built since the restoration of the country's independence. As a result, the overall condition of buildings in Latvia can be assessed as poor or even unsatisfactory. Some multi-apartment buildings are so dilapidated that they endanger the safety and health of both tenants and the surrounding residents. The involvement of apartment owners and managers in the renewal of the housing stock is largely related to financing that they cannot afford to invest themselves. The support mechanism for the renovation of multi-apartment residential buildings is the European Union funds, as well as the Investment and Development Agency of Latvia (LIAA) and ALTUM. In the ALTUM programme, the maximum grant or gift limit is $50 \%$ of the total eligible costs, while the other part of the financing is covered through a commercial bank that has a cooperation agreement with ALTUM or the funds or savings of the tenants. LIAA and ALTUM support programmes have different funding models. As a result of the research, it has been proven that the renovation of multi-apartment buildings is a complex, financially expensive and complicated project that cannot be implemented without the European Union co-financing.
\end{abstract}

Keywords: multi-apartment buildings, co-financing mechanisms, renovation, ALTUM, LIIA

\section{INTRODUCTION}

The gas that has the greatest impact on the greenhouse effect is $\mathrm{CO} 2$. The concentration of $\mathrm{CO} 2$ in the atmosphere has been steadily increasing over the years. As the carbon biogeochemical cycle and the mechanisms that make it run are highly inert, half of today's $\mathrm{CO} 2$ emissions would take a century for the atmosphere to get rid of. Due to this fact, the warming trend will continue even if global greenhouse gas emissions are drastically reduced. Therefore, adaptation to new climate scenarios is inevitable. This effect exacerbates the intensity of extreme weather events, changes in average temperatures, and changes in seasonal characteristics. These changes are in line with the projections of the United Nations Climate Change Agency (Intergovernmental Panel on Climate Change - IPCC) in its periodic assessment reports (Life Adaptate, 2020).

Greenhouse gas emissions cause climate change, irrespective of their production source. Emissions that are dispersed in the atmosphere affect the entire planet. This global trend makes international coordination very important, which is why the Framework Convention on Climate Change was signed in Rio de Janeiro in 1992. Many meetings and Conferences of the Parties (COPs) have taken place since 1992. The SOPs, composed of all states or 'parties', is the decision-making body of the Convention. It meets every year at world conferences (Life Adaptate, 2020).

The 18th meeting of the United Nations Framework Convention on Climate Change (COP 18) in Doha in 2012 extended the Kyoto Protocol's commitment period, which was due to end in 2012, until 2020. The 21st meeting took place in Paris from 30 November to 11 December 2015 (COP 21). In Paris, COP 21 adopted the Paris Agreement, a new protocol that replaced the Kyoto Protocol from 2020 onwards.

The parties reached a new global agreement on climate change. The agreement presents a balanced outcome with an action plan to limit global warming 'well below' $2{ }^{\circ} \mathrm{C}$.

The main elements of the new Paris Agreement:

Long-term goal: governments agreed to keep rise in global average temperature well below $2{ }^{\circ} \mathrm{C}$ compared to the pre-industrial levels and to seek to limit temperature rise to $1.5^{\circ} \mathrm{C}$;

Investment: before and during the Paris Conference, countries presented comprehensive national climate action plans to reduce emissions;

Copyright (C) 2021 The Authors. Published by Vytautas Magnus University. This is an open-access article distributed under the terms of the Creative Commons Attribution License (CC BY 4.0), which permits unrestricted use, distribution, and reproduction in any medium, provided the original author and source are credited. 
Ambitions: governments agreed to announce their investments every five years to set more ambitious targets;

Transparency: they also agreed to report to each other and to the public on their progress towards the objectives set, in order to ensure transparency and oversight;

Solidarity: the EU and other developed countries will continue to provide climate finance to help developing countries both reduce emissions and increase their resilience to the effects of climate change (European Council, 2020).

Latvia has a clearly arranged legal regulation in the field of house management and administration; however, it is not able to address the development issues and perspectives of the arrangement of multi-apartment buildings.

Only in the past ten years, increased attention has been devoted to the poor condition of the housing stock and the need to renovate both existing buildings and build new ones. There is also the need to develop a clear support policy for the arrangement of the housing stock at the national level (Joksts, 2016).

The aim of the article is to study the available support and co-financing mechanisms for the renovation of multiapartment buildings in Latvia. The situation of the multi-apartment residential building stock in Latvia deteriorates every year, its overall development and renovation of houses will be one of the national priorities in the coming years. The following hypothesis is put forward: The renovation of multi-apartment buildings in Latvia is implemented with the EU co-financing.

The main tasks of the study are as follows:

1) to study the general condition of multi-apartment buildings in Latvia, to find out the causes and solutions of the main problems; 2) to consider the support programmes implemented in Latvia for buinling renovation, to find out the amount of available funding, conditions and features of support mechanisms, as well as to compare and analyse the programmes; 3 ) to perform an analysis and compare the building before and after the renovation, to identify benefits, as well as the positive and negative aspects.

Within the framework of the research, general scientific research methods have been used: analysis, synthesis and logical construction methods, including the analysis of written works, which involve research on the topic, press publications, regulations, as well as interviews, in which the comparison of co-financing support programmes available in Latvia will be evaluated from the point of view of experts that deal with these issues on a daily basis.

\section{RESULTS AND DISCUSSION}

\section{Part One}

Despite the volume of data generated, scientists, cannot acccurately predict how climate change will manifest itself locally and what measures should be applied to mitigate it effectively (Cravero et al., 2020).

Climate change is increasingly affecting citizens and businesses. In the latest Eurobarometer survey in 2019, which focused on climate change, respondents ranked it second in the world, after poverty (first) and before international terrorism (third). They agreed on the urgent need to combat climate change. The results, both at the European level and in each Member State, show a significant sensitivity of the population. 92\% of respondents (and more than eight out of ten in each Member State) agree that greenhouse gas emissions should be kept to a minimum while offsetting remaining emissions in order to make the EU economy climate-neutral by $2050.79 \%$ of respondents believe that action on climate change will make EU companies more innovative and competitive. The majority agrees that reducing fossil fuel imports from outside the EU can increase security of energy supply and benefit the EU (72\%). Seven out of ten respondents (70\%) agree that adapting to the negative effects of climate change can have a positive impact on EU citizens (Life Adaptate, 2020).

The European Parliament declared a climate emergency on 28 November 2019. With this Communication, the Parliament calls on the European Commission to ensure that all budgetary and legislative proposals are in line with the Paris Agreement's goal of limiting global warming to below $1.5^{\circ} \mathrm{C}$ (European Parliament, 2019).

Climate change is a threat to all lives on the Earth, yet very little is being done to address the issue at hand (Dunlap, Brulle, 2015).

Climate change emergency is considered to be the no. 1 threat to humanity at the moment. However, the actions taken in response are considered far away from the needed to assure sustainability (Paris, Bland, 2019).

More recently, climate change has been gaining attention in the public debate because of Greta Thunberg, a young Swedish environmental activist who has been promoting worldwide demonstrations to ask governments for concrete action (Pileggi, Lamia, 2020).

The European Union, as a world leader in climate change policy, not only sets emission reduction targets for the Member States, but also attracts public investment in climate change mitigation and adaptation. For the period of $2021-$ 2027, it will be mandatory for the European Structural Funds, which support the Member States, to contribute at least $25 \%$ to spending on climate targets. In this context, many of the measures that regional or local authorities are planning or forecasting within this strategy will need to find financial support (Life Adaptate, 2020).

\section{Part Two}

Management of residential buildings is an organized and efficient system that includes legal and technical actions to solve building maintenance problems. (Puķīte, 2016).

In Latvia, most of all existing dwellings were built during the Soviet years, including multi-apartment buildings, which were constructed on a mass scale at that time. Thus, the current situation is reflected in the current reality - the high level of depreciation of the housing stock and the poor overall condition. According to the 2020 report of the Organization for Economic Co-operation and Development (OECD), 66\% of all buildings were constructed during the Soviet period (1946-1990) (OESC Report, 2020). As shown in Figure 1, 12\% of the buildings were constructed in the 
period of 1919-1945, while only about $10 \%$ of buildings - after the restoration of independence (OECD Report, 2020). This makes up a very small number of buildings from the total number of houses.

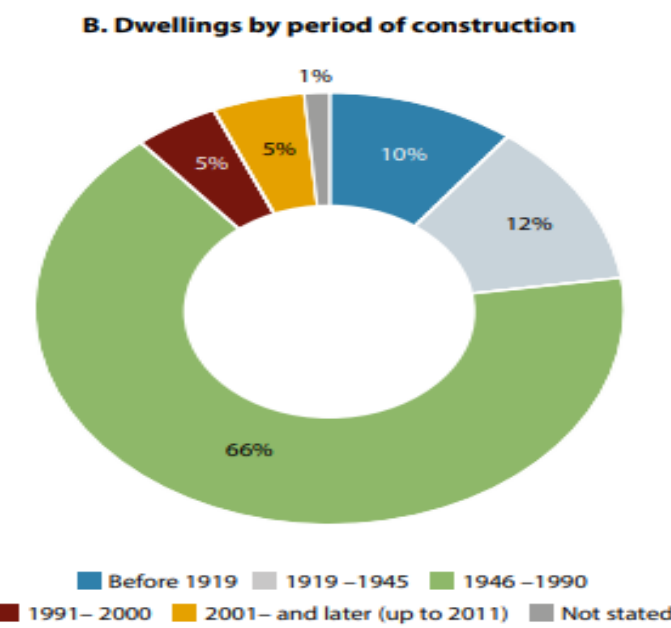

Figure 1. Construction of dwellings by year (OECD Report, 2020).

In the case of multi-apartment buildings, according to the data of the State Land Service, the number of three- or more apartment buildings is 39,477 with the total area of $51 \mathrm{mln} . \mathrm{m}^{2}$, which is almost $25 \%$ of the total area of all buildings. (Ekonomikas Ministrija, 2020). The beginnings of the construction of multi-apartment buildings can be traced back to the 1940s, when the typical construction projects of Stalin's time began, with typical brick buildings. Then, from the 1960s to the 1980s, the active construction of various standard houses took place: 464 series buildings followed by 103 and 104 series buildings. At the end of the period, the construction of the nine-storey 602 series buildings began. (Ekonomikas Ministrija, 2020). This series buildings already consisted of reinforced concrete panels and slabs.

In the early 1990s, with the restoration of independence, the situation in the field of multi-apartment building construction changed dramatically. The restoration of independence, the establishment and development of a democratic system, the difficult economic situation in the country as a whole and other problems of that time practically pushed aside the construction of new multi-apartment buildings. In 1991, new stricter requirements for building envelopes were also set. In the following years, these requirements became even more stingent, until a law was passed in 2019, (Ekonomikas Ministrija, 2020) which stipulated that from 2021, all new buildings had to be nearly zero-energy buildings.

The audit report on the safety of buildings published by the State Audit Office (hereinafter - SAO) in 2019 also reflected a relatively critical picture in the field of multi-apartment buildings, which once again caused public resonance on this issue. The audit report was based on the inspection of various buildings managed by the municipalities and the deficiencies and defects identified as a result of the inspection. Of the 82 multi-apartment buildings inspected, 62 were found to have various types of defects, which at the same time indicated the poor technical condition of the buildings and that they were not maintained in proper technical condition (Latvijas Republikas..., 2019).

Another problem related to the renewal of the housing stock, which was also indicated by the SAO in its audit report, is inconformity of house management and administration fees to real estimates of house maintenance expenses and often decisions on management fees were made at least ten years ago (Latvijas Republikas..., 2019). Therefore, the set management fees are much lower and it is not possible to ensure the physical maintenance and preservation of houses as required by the national laws and regulations. A similar picture emerges from an OECD report, which found low house maintenance and repair costs. At the same time, low household affordability prevents the purchase of new, better housing (OECD Report, 2020). The report also reveals that total household expenditure on housing, including repairs and maintenance, has been relatively low since 1995, when the privatization process began.

The general situation in the field of multi-apartment buildings is further aggravated by the fact that many multiapartment series buildings constructed during the Soviet period are approaching the end of service life, as shown in Table 2. Consequently, in the near future, special attention should be paid to the technical condition and safety of buildings that are approaching the final phase of their service life.

Table 2. Average service life of multi-apartment series buildings (Rīgas namu pārvaldnieks, 2017)

\begin{tabular}{|l|l|l|l|}
\hline Building series, type & Construction period & Average service life & Expiration date \\
\hline Stalin's time project & $1945-1950$ & 150 & $2095-2100$ \\
\hline 316 and 318 series (Khrushchev's time project) & $1955-1970$ & 70 & $2025-2040$ \\
\hline 464 series (Lithuanian project) & $1960-?$ & 60 & $2020-+$ \\
\hline 467 series & $1970-1980$ & 60 & $2030-2040$ \\
\hline 103 series & $1970-1990$ & 60 & $2030-2050$ \\
\hline 104 series & $1970-?$ & 60 & $2030-+$ \\
\hline Czech project & $1970-1980$ & $60 ?$ & $2030-2040$ \\
\hline 602 series & $1975-1980$ & 60 & $2035-2040$ \\
\hline 19 series & $1980-?$ & 70 & $2050-+$ \\
\hline
\end{tabular}


In addition, many buildings, as demonstrated in the audit report by the SAO, are not properly maintained, which further reduces their overall service life. Apartment owners in multi-apartment buildings often carry out arbitrary re-planning and reconstruction of premises, which is especially dangerous in cases when the load-bearing walls are affected or their volume is reduced, which creates additional load on other load-bearing element structures.

As a result, summarising the aforementioned factors, it should be concluded that the statement above is confirmed, i.e., the existing housing stock in Latvia is in a poor technical condition and is becoming obsolete. This is due to a set of interactions of several factors - the state policy on housing is not clearly defined, the inability of apartment owners to take responsibility and care of multi-apartment buildings as a joint property, as well as low income does not allow purchasing a new dwelling, which at the same time hinders the overall development of the housing market.

\section{Part Third}

\section{Co-financing Programmes for the Renovation of MULTI-APARTMENT Buildings}

The European Union funds are the largest source of financial resources for the renovation of multi-apartment buildings in Latvia. In 2009, co-financing from the EU funds became available for the renovation of multi-apartment buildings (Ekonomikas Ministrija, 2020). During the period of the fund, i.e., the period of 2007-2013, a total of 741 multi-apartment buildings were renovated in Latvia (Ekonomikas Ministrija, 2020). The total investment amounted to 149 million EUR - the European Regional Development Fund (hereinafter - ERDF) financing amounted to 63 million EUR and private co-financing - 86 million EUR. The heat savings in the completed projects reached $30-60 \%$ of the previously consumed heat (Ekonomikas Ministrija, 2017). Overall, this can be considered as an effective reduction in consumption.

During the EU fund programming period of 2007- 2013, 1440 project applications were received (Ekonomikas Ministrija, 2017). While the number of projects submitted in the first two years was relatively small - 117 and 170 projects submitted, respectively, in the third year or in 2010 the number of projects submitted almost tripled compared to the previous year. A similar trend was observed in 2011. Only last year was again characterised by the reduced activity, although it still remained much higher than in the first two years of project submission.

Out of a total of 1440 project applications, the implemented 741 renovation projects accounted for approximately $50 \%$ of the total number of submitted project applications in the respective period.

If we take a closer look at the total use of project funding (Table 3), it can be seen that from the costs of all projects, co-financing and private financing accounted for practically the same financial distribution, i.e., 63219895 million EUR vs. 63024534 million EUR, which coincided with the maximum allowable support financing in the amount of 50\%, which was determined in Article 21 of the "Regulation on Operational Programme "Infrastructure and Services" Complement's Activity 3.4.4.1 "Improvement of Heat Insulation of Multi-Apartment Residential Buildings"”. (Latvijas Republikas Saeima, 2009). At the same time, Table 3 also shows the ineligible costs of projects in the amount of $23478465 \mathrm{mln}$., which had to be covered by the apartment owners themselves from a private financing source. Ineligible costs are defined in Article 19 of the above-mentioned regulation, which stipulates that ineligible costs include improvement and landscaping, losses related to the ownership of individual apartments, interest payments, fines, penalties and other similar payments. In total, ineligible costs accounted for more than $15 \%$ of total investment.

Table 3. The number of implemented projects and financing in the EU fund programming period of 2007-2013 (Ekonomikas Ministrija, 2017)

\begin{tabular}{|l|l|l|l|l|l|}
\hline $\begin{array}{l}\text { Project } \\
\text { status }\end{array}$ & $\begin{array}{l}\text { Number of } \\
\text { projects }\end{array}$ & $\begin{array}{l}\text { ERDF funding } \\
\text { (EUR) }\end{array}$ & $\begin{array}{l}\text { Private eligible } \\
\text { funding (EUR) }\end{array}$ & Ineligible costs (EUR) & $\begin{array}{l}\text { Total investment } \\
\text { (EUR) }\end{array}$ \\
\hline Completed & 741 & 63219895.92 & 63024534.16 & 23478465.53 & 149722895.61 \\
\hline
\end{tabular}

If we compare the number of renovated buildings in the respective city against the total number of buildings, it can be concluded that most of the buildings in the country are still waiting for their renovation, as the total number of renovated buildings against the total number of buildings is relatively small.

Table 4. Proportion of buildings renovated in the most active municipalities in relation to their total number of residential buildings (Ekonomikas Ministrija, 2017).

\begin{tabular}{|l|l|l|l|l|l|}
\hline Project status & Riga & Valmiera & Liepāja & Ventspils & Cēsis \\
\hline \multicolumn{1}{|c|}{ Completed } & 46 & 60 & 110 & 57 & 28 \\
\hline $\begin{array}{l}\text { Total number of buildings (data of } \\
\text { the State Land Service) }\end{array}$ & 11913 & 453 & 2117 & 828 & 432 \\
\hline $\begin{array}{l}\text { The ratio of the insulated } \\
\text { buildings to the total number of } \\
\text { buildings, \% }\end{array}$ & $\mathbf{0 . 3 9 \%}$ & $\mathbf{1 3 . 2 5 \%}$ & $\mathbf{5 . 2 \%}$ & $\mathbf{6 . 8 8 \%}$ & $\mathbf{6 . 4 8 \%}$ \\
\hline
\end{tabular}

After the end of the programme implementation period, the preparation phase for the 2014-2020 programming period of the European Union Structural Funds and the Cohesion Fund began. The operational programme "Growth and Employment" envisaged funding to Latvia in the amount of more than 4.4 billion (Latvijas Republikas..., 2020). The preparation phase included a number of changes compared to the previous period.

According to the implementation regulations of the operational programme "Growth and Employment", specific support objective measure 4.2.1.1 "To promote energy efficiency in residential buildings" of specific support objective 4.2.1 
"To promote the increase of energy efficiency in public and residential buildings", the total funding for the implementation of the measure "To promote energy efficiency in residential buildings" amounts to 201462726 EUR, including the EU fund (hereinafter-ERDF) financing of 171234317 EUR and state budget co-financing of 30219409 EUR. The regulations also stipulate that ALTUM is the implementer of the financial instrument. (Latvijas Republikas..., 2016).

The largest benefit from ALTUM participation is not only a neatly-arranged house with high value and increased life service, but also significantly reduced energy consumption. Before the renovation of the building, the average energy consumption was $165 \mathrm{kWh}$ per year, after renovation works it was $54 \mathrm{kWh}$ per year or on average by 67\% lower (ALTUM, 2020). Energy efficiency is one of the main criteria on which project applications are based. According to the regulations, after renovation, the average heat consumption for heating of multi-apartment residential buildings per calendar year may not exceed $90 \mathrm{kWh} / \mathrm{m}^{2}$. (Latvijas Republikas..., 2016). To sum up, the lower the consumption, the greater the savings on total heat costs.

As shown in table 5, a total of 989 energy efficiency improvement projects were submitted in the period from 2016, when ALTUM started accepting projects, to December 2020, when ALTUM stopped accepting additional project applications. According to the data, most of the house renovation works are still ahead. Of the 989 projects submitted, only 263 buildings have been completely renovated, accounting for about $20 \%$ of the total number

Table5. ALTUM data on the renovation projects submitted as of 7 January 2021 (ALTUM, 2021).

\begin{tabular}{|c|c|c|c|c|}
\hline 989 & 688 & 333 & 47 & 263 \\
\hline Submitted projects & $\begin{array}{c}\text { Positive technical } \\
\text { opinions }\end{array}$ & $\begin{array}{c}\text { Positive grant } \\
\text { decisions }\end{array}$ & $\begin{array}{c}\text { In the renovation } \\
\text { process }\end{array}$ & $\begin{array}{c}\text { Renovations } \\
\text { implemented }\end{array}$ \\
\hline
\end{tabular}

However, it is likely that a certain percentage of the submitted projects will not be implemented, and they will fail due to various reasons - the inability of apartment owners to agree on a loan in one of ALTUM cooperation banks, the inability to agree on total construction costs, especially for positions included in the ineligible costs, etc.

According to ALTUM data, the average cost of one multi-apartment buiding renovation project is 430 thousand EUR, of which 215 thousand or half of all eligible costs are allocated in the form of a grant or gift (ALTUM, 2020). The second part is used as a loan in one of the ALTUM cooperation banks; in the current economic conditions practically no multi-apartment building is able to collect such amount on its own.Examining a wider ten-year period, starting from 2009, when the renovation of multi-apartment buildings began in Latvia, until 2019, a total of 802 buildings were renovated in the entire territory of the country (ALTUM, 2019). Looking at this period of time by regions, the most part of renovated buildings belongs to Kurzeme region - 245 buildings, followed by Riga region with 240 buildings and Vidzeme with 178 buildings. The most active cities with apartment owners are Liepāja, where a total of 114 apartment buildings were renovated, while 64 buildings were renovated in Valmiera, 57 - in Ventspils, 50 - in Rīga and 19 - in Jelgava (Ekonomikas Ministrija, 2015). The Ministry of Economics has estimated that with the renovation of existing buildings in the country, $5 \%$ of all multi-apartment buildings will be renovated, the total number of which is about 40 thousand. (ALTUM, 2020). At the same time, it lags far behind the planned long-term indicators, in accordance with the goals set in the National Development Plan (hereinafter - NDP).

\section{Comparative Evaluation of Co-financing Programs}

In Latvia, the former LIAA renovation support programme and the ALTUM renovation programme currently implemented have their own conditions, criteria and restrictions, which are set for those multi-apartment buildings that are willing to obtain a grant for energy efficiency improvement and renovation works within the programme.

In order to be able to compare the two programmes, as well as to evaluate their advantages and disadvantages, which should be taken into account and eliminated within the framework of future building renovation support programmes, three different project management companies were interviewed - Ltd. Ādažu namsaimnieks, Ltd. Rīgas namu pārvaldnieks and Ltd. Adax. These experts were selected based on the criterion that they all had practical experience in working with both the former LIAA programme and the current ALTUM programme. All experts were asked similar questions in order to make the best possible comparison of the two programmes.

On the way to renovation and support co-financing or obtaining a grant in the ALTUM programme, any multiapartment building has two possible options: either the renovation project is led through the house manager or a qualified project manager is attracted, with renumeration for the services provided. The building can also manage itself through an association or other legal status and then there can be both a house manager and a project manager. The amount of remuneration for the project manager to be included in the eligible costs is specified in the ALTUM conditions and the total amount of project management costs may not exceed 3\% of the total eligible costs (ALTUM, 2020). If the amount is more than $3 \%$, the remaining amount is already ineligible costs.

According to the interviewed project managers, this is one of the main problems within the existing ALTUM programme. It is a very complicated and difficult task for the heads of housing associations to carry out the renovation project on their own without the involvement of a competent project manager. It is necessary to understand both regulatory enactments and the sphre of construction, as well as to know technological processes and properly draw up all necessary documents; within the project there are also many different changing nuances, which are also unpredictable. Experts also emphasise that sometimes the relevant document forms change so often that it is difficult to follow and draw up the relevant documents in advance, as changes in the ALTUM documentation may occur at any time during the project development. 
Another pronounced problem mentioned by the interviewed experts within the existing programme is the scrupulous and sometimes even overly detailed approach of ALTUM staff to the examination of project documentation and compliance with conditions, which greatly complicates the overall project progress and extends project implementation deadlines. This problem is acknowledged by all the interviewed experts. Coordinating the documentation at all stages of the project with ALTUM specialists takes up to three times more time than it was within the LIAA programme. In terms of time, it can extend the project implementation period up to two years. Within the framework of the LIAA programme, the coordination process was faster and simpler, as only the application documentation was checked, but the technical part of the project documentation was left to the construction board. ALTUM specialists check absolutely all documentation and, as a result, a situation may arise when there is a request for changes to the technical project, which has already received the approval of the construction board, as a result of which the renovation project no longer complies with the project version agreed by the construction board.

Experts mention various reasons for such scrupulous examining and coordinating of documentation. One of the reasons is ALTUM understanding of things and doing things that should not be done at all. The opinion is expressed that it is due to the desire of ALTUM and officials of the responsible ministries to protect themselves and their reputation from possible risks in case of mistakes during the project development and implementation. As a result, no one thinks at the national level, but only is concerned about preserving one's position and reputation, so that in the event of an unforeseen scenario, the officials concerned cannot be held liable.

It is possible that such an approach implemented by ALTUM can be attributed to the supermarket tragedy in 2013, when 54 people died due to the collapsion of store structures (LA.LV, 2019). The cause of the tragedy was incorrectly calculated roof structure loads, which resulted in the collapse of a part of the building. It is possible that precisely for this reason, in order to prevent the recurrence of such cases, a scrupulous examination of the technical documentation by ALTUM specialists is performed.

As the experts themselves admit, such an approach also has its positive side - as a result, the developed projects are of higher quality than during the times of LIAA. At the same time, experts believe that it is not so important and against this background the long coordination time does not justify it. All these small faults could be prevented and solved during the further implementation of the project. There is also no published or available ALTUM study that would highlight an overall benefit from the long deadlines for testing and project coordination.

Comparing the two programmes, the experts emphasise that the funding model has also changed significantly. If during the times of LIAA a bank loan of $100 \%$ of the total costs was required and after the construction half of the financing was returned through the grant, then within the ALTUM practice the grant financing is initially $50 \%$ and the remaining $50 \%$ and additional ineligible costs are taken as a loan in a commercial bank. At the same time, both models have their advantages and disadvantages. In the case of LIAA, initially there is a much larger loan amount, as a result of which much larger loan payments have to be paid to the bank in the first years until the reception of a grant, from which the existing loan amount at the bank is partially covered. If there were any adjustments within the project, then, according to the experts, none of these adjustments were felt by the builders, the designer or the apartment owners. In turn, in the ALTUM programme the situation is more complicated - if financial corrections occur during the project implementation, then the question of where to find the necessary financing is very topical, because the costs have already been agreed and approved. According to the experts, as a possible solution could be to anticipate a possible percentage of financial corrections when voting on the project costs from the very beginning, which should then be taken into account during the project implementation.

Within the framework of corrections, difficulties also appear in cases when it is necessary to change building materials. The process of re-approving the materials takes a very long time and ALTUM follows its own guidelines, which are sometimes not understood by the other parties involved in the project.

Sometimes, when the project is delayed, situations arise when the materials or technologies selected for construction are no longer available - new materials have come in place, as a result of which the solutions provided for in the project are no longer available. As a result, ALTUM requires certificates from the material manufacturer's factory and other documents, which further extends the project deadlines and complicates the project implementation.

As part of the comparison of the programmes, the experts mention a low level of consistency, especially in the ALTUM programme. The lack of consistency is reflected, firstly, in the documentation. The experts point out that various application forms and guidelines change very often, which makes it difficult to keep track of frequent changes in documentation and draw up the necessary documents in a timely manner. They also mention inconsistency in staffing ALTUM staff changes frequently, and each new employee has their own understanding of the progress of each respective project and the necessary documentation; as a result, additional documents are often requested, which were not necessary before. It is never possible to predict or know for which project the responsible specialist from ALTUM may change at some point.

It is necessary to keep track of changes to the ALTUM guidelines and any of the forms, as missing any corrections to the formatting and submission of the requested form may result in errors that can no longer be corrected and can be costly for the project as a whole, especially, if the documents are not drawn up by a respective project manager but an available sample is taken.

The experts mention the key elements that need to be changed in the long term: easing the conditions for project coordination and shortening project deadlines, changing the approach of ALTUM specialists themselves and ensuring greater support and consistency, as well as rethinking the current project co-financing model, especially in the context of corrections and adjustments. 


\section{CONCLUSIONS}

At present, the pace of climate change is a strong warning of the irreversible effects of climate change, which call for urgent action. However, if action is taken in good time, it is still possible to halt and reduce the intensity of climate change so that the consequences are less devastating. Therefore, it is crucial that countries make decisions and implement policies, including financial support, that will enable them not only to adapt to the expected changes, but also to slow down the progression and impact of climate change.

Renovation of multi-apartment buildings at the national level has been implemented since 2009 with the support of the EU co-financing or grant donation within the framework of two LIAA and ALTUM programmes. The LIAA programme and the acquisition of the EU co-financing were implemented from 2009 to 2013. ALTUM, in its turn, took over the powers of the multi-apartment building renovation programme from LIAA in 2014 and carries out the renovation of buildings until now, while the acceptance of project applications closed at the end of 2021.

Currently, the renovation of multi-apartment buildings without the financial support of the EU programmes is practically impossible in Latvia.

Having evaluated and compared LIAA and ALTUM programmes, several important conclusions can be drawn.

First, the programs are different from each other in terms of the funding model implemented. During the times of LIAA, financing or grant donation was awarded only after the implementation of the project, initially the tenants of the renovated building took the full loan amount in one of the banks, which was then partially covered by the payment of the received co-financing. In turn, in the ALTUM programme, co-financing or a grant is initially awarded and then a loan for the remaining amount is taken in one of the banks. The advantage of such a model is manifested in lower loan interest payments to the bank, but it also has its drawbacks. As one of the main disadvantages, which is also acknowledged by the interviewed experts, is that within the project, if financial corrections are made and additional funding is needed to perform some work, then the question arises as to where to take this missing funding. One of the possible solutions is to anticipate possible corrections or adjustments from the outset and to reserve an appropriate amount, which may have to be taken into account during the project implementation.

The positive aspect - much more information about the ALTUM programme is available, various educational seminars are regularly organised and samples of different types of documents are available on the ALTUM website, which facilitates the process of drawing up the documentation.

In general, the renovation programmes of multi-apartment buildings during the times of both LIAA and ALTUM have been successful, and the desired effect has been achieved. This is also proven in practice, as by renovating multiapartment buildings not only their service life is prolonged, but also a well-maintained environment is created and energy consumption is reduced. Moreover, the overall benefit is reflected in the population's bills - as a result of energy efficiency measures, expenditure on heating, planned repairs, and water heating decreases to a level that is equal to the repayment of the loan to the bank.

Multi-apartment building owners are becoming more aware of the benefits of building renovation, as evidenced by all the co-financing acquired under the ALTUM programme, including additional state funding, so that as many residential buildings as possible can participate in the programme, despite the long and difficult project coordination process.

The hypothesis The renovation of multi-apartment buildings in Latvia is implemented with the EU co-financing put forward at the beginning of the article is partially proven. Renovation of multi-apartment buildings is a complex, financially expensive and complicated project that cannot be implemented without the support of the European Union funds. At the same time, commercial banks, which provide the necessary part of the loan, also play an important role in the renovation of residential buildings, as well as the tenants of the buildings, who are ready to make long-term commitments and decide to renovate the building.

\section{REFERENCES}

1. European Council. 2020. Paris UN Climate Change Conference, 30 November - 12 December 2015. Available at https://www.consilium.europa.eu/en/meetings/international-summit/2015/11/30-12/ (accessed on 15/11/2021)

2. European Parliament. 2019. The European Parliament Declares Climate Emergency. Available at https://www.europarl.europa.eu/ news/en/press-room/20191121IPR67110/the-european-parliament-declares-climate-emergency (accessed on 15/11/2021)

3. Dunlap, R. E., Brulle, R. J. 2015. Climate Change and Society: Sociological Perspectives. Oxford, UK: Oxford Univ. Press, 2015. https://doi.org/10.1093/acprof:oso/9780199356102.001.0001

4. Joksts, O., Girgensone, B., Mihailovs, I. J. 2016. Terminu skaidrojošā vārdn̄̄ca Civiltiesības (Lietu tiesības), SIA Drukātava, Rīga.

5. Puḳ̄te, I. 2016. Dzīvojamo ēku pārvaldīšanas sistēmu ietekmējošie faktori//Juridiskās koledžas zinātniskie raksti, Juridiskā koledža, Rīga.

6. OECD. 2020. OECD Report: Policy Actions for Affordable Housing in Latvia. Available at https://issuu.com/oecd.publishing/ docs/latvia_housing_report_web-1 (accessed on 18/02/2021)

7. Ekonomikas Ministrija. 2020. Informatīvais ziņojums “Ēku atjaunošanas ilgtermiṇa stratēgija'. Available at https://ec.europa.eu/ energy/sites/ener/files/documents/lv 2020 ltrs.pd (accessed on 18/02/2021)

8. Latvijas Republikas Valsts kontrole. 2019. Ēku drošums: vai darām pietiekami? Available at https://www.lrvk.gov.lv/lv/revizijas/ revizijas/noslegtas-revizijas/vai-tiek-izpilditi-prieksnoteikumi-pasvaldibu-parvaldisana-un-kontrole-esosu-ekspluatacija-pienemtu -eku-atbilstibai-drosuma-prasibam ( accessed on 18/02/2021) 
9. Rīgas namu pārvaldnieks. 2017. Daudzdzīvokḷu māju atjaunošanas iespējas. Available at https://www.slideshare.net/siltinam/ daudzdzvoku-mju-atjaunoanas-iespjas-rga (accessed on 18/02/2021)

10. Ekonomikas Ministrija. 2015. 10 gadu laikā Latvijā atjaunotas 802 daudzdzīvokḷu ēkas; vairāki simti projektu vēl ir īstenošanas stadijā. Available at https://www.esfondi.lv/jaunumi/em-10-gadu-laika-latvija-atjaunotas-802-daudzdzivoklu-ekas-vairaki-simtiprojektu-vel-ir-istenosanas-stadija?print=1. ( accessed on 18/02/2021)

11. Ekonomikas Ministrija. 2017. Informatīvais ziņojums “Ēku atjaunošanas ilgtermiṇa stratēgija”'. Available at https://ec.europa.eu/ energy/sites/default/files/documents/lv_building_renov_2017_lv.pdf (accessed on 18/02/2021)

12. Latvijas Republikas Saeima. 2009. Noteikumi par darbības programmas "Infrastruktūra un pakalpojumi” papildinājuma 3.4.4.1.aktivitātes "Daudzdzīvokḷu māju siltumnoturības uzlabošanas pasākumi" projektu iesniegumu atlases pirmo līdz astoto kārtu. Available at https://likumi.lv/ta/id/188595-noteikumi-par-darbibas-programmas-infrastruktura-un-pakalpojumi-papildinajuma-3441 aktivitati-daudzdzivoklu-maju-siltumnoturibas-uzlabosanas-pasakumi ( accessed on 18/02/2021)

13. Latvijas Republikas Finanšu ministrija. 2020. LIAA direktors A. Ozols klaji maldina sabiedrību par ES fondu 2014.-2020. Plānošans periodu. Available at https://www.esfondi.lv/jaunumi/liaa-direktors-a.-ozols-klaji-maldina-sabiedribu-par-es-fondu2014.-2020.gada-planosanas-periodu (accessed on 14/02/2021).

14. Latvijas Republikas Saeima. 2016. Darbības programmas "Izaugsme un nodarbinātība" 4.2.1. specifiskā atbalsta mērḳa "Veicināt energoefektivitātes paaugstināšanu valsts un dzīvojamās ēkā" 4.2.1.1. specifiskā atbalsta mērḳa pasākuma "Veicināt energoefektivitātes paaugstināšanu dzīvojamās ēkās” īstenošanas noteikumi. Available at https://likumi.lv/ta/id/281323-darbibas-programmas-izaugsmeun-nodarbinatiba-4-2-1-specifiska-atbalsta-merka-veicinat-energoefektivitates-paaugstinasanu (accessed on 17/02/2021)

15. Altum. Daudzdzīvokḷu ēku atjaunošanai papildus piešḳirti 35 miljoni eiro. Available at https://www.altum.lv/lv/jaunumi/ daudzdzivoklu-eku-atjaunosanai-papildu-pieskirti-35-miljoni-eiro (accessed on 17/02/2021).

16. Altum. 2020. Programmas apguves dati. Available at https://www.altum.lv/lv/pakalpojumi/maju-energoefektivitate-

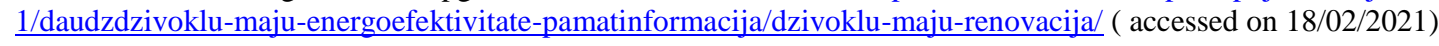

17. Altum. 2020. Daudzdzīvokḷu māju renovācijas programmai papildus iesniegts 101 projekts; kopumā tiks atjaunotas vairāk nekā 980 mājas. Available at https://www.altum.lv/lv/jaunumi/altum-daudzdzivoklu-maju-renovacijas-programmai-papildus-iesniegts101-projekts-kopuma-tiks-atjaunotas-vairak-neka-980-majas (accessed on 18/02/2021)

18. Ekonomikas Ministrija. 2020. 10 gadu laikā Latvijā atjaunotas 802 daudzdzīvokḷu ēkas; vairāki simti projektu vēl ir īstenošanas stadijā. Available at http://www.energoefektivakaeka.lv/index.php/home/jaunumi/319-10-gadi-dm-energoefektivitatei (accessed on $18 / 02 / 2021$ )

19. IR Liepāja. 2019. Atjaunotas 802 daudzdzīvokḷu ēkas, Liepāja starp līderēm. Available at https://irliepaja.lv/vide/atjaunotas-802daudzdzivoklu-ekas-liepaja-starp-liderem/ ( accessed on 18/02/2021)

20. Altum. 2020. Projekta vadības izmaksas. Available at https://www.altum.lv/lv/pakalpojumi/maju-energoefektivitate/programmasatbalsts-grants/projekta-vadibas-izmaksas/ (accessed on 18/02/2021)

21. LA.LV. 2019. Aprit seši gadi kopš Zolitūdes traǵēdijas “ Maxima” lielveikalā. Available at https://www.la.lv/aprit-sesi-gadi-kopszolitudes-tragedijas-maxima-lielveikala (accessed on 18/02/2021)

22. Life Adaptate. 2020. Guidelines for Improving Local Government Policies to Include Climate Change Mitigation and Adaptation. Available at https://lifeadaptate.eu/wp-content/uploads/LIFEAdaptate-policy-guideline_LV.pdf (accessed on 15/11/2021)

23. Cravero, A., Sepulveda, S., Munoz, L. 2020. Big Data Architectures for the Climate Change Analysis: A Systematic Mapping Study. Ieee Latin America Transactions, Vol. 18, No. 10, October 2020, pp. 1793-1806. https://doi.org/10.1109/TLA.2020.9387671

24. Paris, G., Blards, P.H. 2019. CO2 Levels and Climate Change: Is There Really a Controversy? Available at https://theconversation.com/co-levels-and-climate-change-is-there-really-a-controversy-119268 (accessed on 15/11/2021)

25. Pileggi, S., Lamia, S. A. 2020. Climata Change Time Line: An Ontology to Tell the Story so Far. IEEE Acess. https://doi.org/10.1109/ACCESS.2020.2985112 